\title{
Inhibition of Ethylene Biosynthesis and Perception by 1-Methylcyclopropene and Its Consequences on Chlorophyll Catabolism and Storage Quality of 'Bosc' Pears
}

\author{
Xingbin Xie ${ }^{1}$ \\ Department of Horticulture, Mid-Columbia Agricultural Research and Extension Center, Oregon \\ State University, 3005 Experiment Station Drive, Hood River, OR 97031 \\ Congbing Fang \\ Department of Horticulture, Anhui Agricultural University, Hefei, China 230036 \\ Yan Wang ${ }^{2}$ \\ Department of Horticulture, Mid-Columbia Agricultural Research and Extension Center, Oregon \\ State University, 3005 Experiment Station Drive, Hood River, OR 97031
}

\begin{abstract}
Additional Index words. Pyrus communis, 1-MCP, ethylene synthesis genes, ethylene signaling genes, chlorophyll degradation genes

Abstract. Bosc is a winter cultivar of european pear (Pyrus communis) that has a relatively short storage life partially due to a high ethylene production rate (EPR) during cold storage. 'Bosc' pears were harvested at commercial maturity and treated with gas 1-methylcyclopropene (1-MCP) at $0,0.15$, and $0.3 \mu \mathrm{L} \cdot \mathrm{L}^{-1}$ and stored at $-1.1{ }^{\circ} \mathrm{C}$ for 8 months. Results indicated that all 1-MCP treatments inhibited EPR and respiration rate (RR), retarded the degradation of chlorophyll and titratable acidity (TA), and extended storage quality; but inhibited ripening capacity. 1-MCP at 0.15 and $0.3 \mu \mathrm{L} \cdot \mathrm{L}^{-1}$ had the same efficacy on keeping fruit quality although its higher rate was more efficient on inhibiting EPR and RR. The expression of ethylene synthesis genes (PcACS1, PcACS2, PcACS4, PcACS5, and PcACO1) and receptor genes (PcETR1, PcETR2, and PcERS1) was upregulated in control fruit during storage and they were downregulated significantly by $1-M C P$ treatments. In contrast, the ethylene receptor genes of $P c E T R 5$ and PcCTRI were downregulated in control fruit during storage and were unaffected by 1-MCP treatments. Although the transcription levels of chlorophyll degradation genes PcPPH, PcNOL, PcSGR, PcRCCR, PcNYC, and PcPAO were all upregulated in control fruit during storage and downregulated by 1-MCP; only $P c C H L$ was downregulated in the control and 1-MCP had no consistent effect on it. The relationship of ethylene biosynthesis/perception with chlorophyll degradation and storage quality in european pears was discussed.
\end{abstract}

'Bosc' is the second most produced winter cultivar of european pear in the Pacific northwesten United States with annual production of about 61 million kilograms (Northwest Horticultural Council, 2013). Although most european pears are normally enjoyed by consumers when they have ripen to a buttery-juicy texture, 'Bosc' pears can be eaten as either a crispy-juicy texture before ripening or a buttery-juicy texture after ripening. Significant storage losses in 'Bosc' pear due to deterioration in eating quality, yellowing, and decay occur commercially in certain production years (Chen, 2004; Chen et al., 1983). A high EPR during cold storage may

\footnotetext{
Received for publication 22 Dec. 2016. Accepted for publication 17 Jan. 2017. This work was also supported by the USDA National Institute of Food and Agriculture Hatch Project, Improving Quality and Reducing Losses in Specialty Fruit Crops through Storage Technologies (NE-1336).

We are grateful to the Columbia Gorge Fruit Growers Association and the NW Fresh Pear Research Committees for financial support.

Any opinions, findings, conclusions, or recommendations expressed in this publication are those of the authors and do not necessarily reflect the view of the National Institute of Food and Agriculture (NIFA) or the U.S. Department of Agriculture.

${ }^{1}$ Current address: Department of Horticulture, Anhui Agricultural University, Hefei, China 230036.

${ }^{2}$ Corresponding author. E-mail: yan.wang@oregonstate.edu.
}

contribute to its relatively low storage potential (Chen et al., 1982, 1983).

In addition to flavor and texture, fruit characteristic skin color is important for consumer acceptance and often an indicator for ripening of european pears (Charoenchongsuk et al., 2015; Kappel et al., 1995). Yellowing caused by chlorophyll degradation in storage is associated with senescence and reduced shipping quality for green-type european pears such as 'Bartlett', 'Bosc', and 'Anjou' (Wang, 2016). Chlorophyll is degraded by a multistep enzymatic process that converts fluorescent chlorophyll into nonfluorescent catabolites (Krautler, 2008). Dephytilation by chlorophyllase (CHL) is the first step in chlorophyll $a$ degradation, producing pheophorbide (Harpaz-Saad et al., 2007). A proposed alternative pathway for producing pheophorbide from chlorophyll $a$ is executed by pheophytinase (PPH) (Schelbert et al., 2009). Pheophorbide is then oxidized into red chlorophyll catabolites (RCCs) by pheophorbide $a$ oxygenase (PAO) (Hortensteiner et al., 1998; Pruzuinska et al., 2003). The RCCs are further modified by RCC reductase (RCCR) that hydrogenates a double bond in the tetrapyrrole ring forming colorless, fluorescent catabolites (FCCs). Finally, FCCs are modified to their respective nonfluorescent chlorophyll catabolites (NCCs) by nonenzymatic tautomerization and stored in vacuoles (Oberhuber et al., 2003). 
Chlorophyll $b$ is degraded after conversion to chlorophyll $a$ and this conversion is carried out by two enzymes: chlorophyll $b$ reductase and 7-hydroxymethyl chlorophyll $a$ reductase (Rüdiger, 2002; Scheumann et al., 1998). Nonyellow coloring 1 (NYC1), similar to a short-chain dehydrogenase/reductase, is required for functioning of the chlorophyll $b$ reductase (Kusaba et al., 2007). NYC-like (NOL) protein is closely related to $\mathrm{NYC1}$, and the expression of both genes is upregulated in senescing tissues. In addition, stay-green (SGR) genes have recently received increasing attention for the role in the chlorophyll degradation process and their expression was found to be closely correlated with plant tissue senescence (Jiang et al., 2007; Sato et al., 2007). A recent study on european pears indicated that the expression of CHL1, PAO, NYC1, and NYC1like gene was lower in a SGR cultivar than a yellowing cultivar during storage (Charoenchongsuk et al., 2015).

Ethylene is a ripening/senescence hormone and is also involved in chlorophyll degradation in fruit peel and plant leaves (Amir-Shapira et al., 1987; Porat et al., 1999). 1-MCP is an ethylene action inhibitor that prevents ethylene-dependent responses such as storage disorders, ripening, and senescence of fruit (Sisler and Serek, 1997; Sisler et al., 2003; Watkins, 2006) including european pears (Argenta et al., 2003; Wang, 2016; Xie et al., 2014, 2015). 1-MCP inhibits CHL activity and maintains green color in vegetables and fruit (Chen et al., 2009; Gong and Mattheis, 2003). Recent studies indicate that 1-MCP can delay chlorophyll degradation in asian pears (Pyrus bretschneideri) by inhibiting ethylene production and suppressing the expression of chlorophyll degradation genes (Cheng et al., 2012; Cheng and Guan, 2014). Although 1-MCP provides valuable benefits in extending storage life of european pears, it interferes with the fruit's ability to ripen normally after storage (Argenta et al., 2003; Xie et al., 2014, 2015). Nevertheless, 1-MCP has been increasingly used commercially on european pears for increasing storage life. However, it is still unclear how 1-MCP affects chlorophyll degradation at the molecular level in european pears.

This work was designed to assess the effect of 1-MCP treatments at harvest on ethylene biosynthesis, chlorophyll degradation, and storage quality of 'Bosc' pears during longterm cold storage. Related gene expression in ethylene synthesis and perception and chlorophyll degradation was also studied to understand the relationship between ethylene function and chlorophyll degradation in european pears during storage.

\section{Materials and Methods}

Fruit AND TREATMENTs. 'Bosc' pears were harvested at commercial harvest maturity of fruit flesh firmness $(\mathrm{FF}) \approx 68.7$ $\mathrm{N}$ in 2014 from mature trees in the orchard of Mid-Columbia Agriculture Research and Extension Center in Hood River, OR (lat. $45.7^{\circ} \mathrm{N}$, long. $121.5^{\circ} \mathrm{W}$, elevation $150 \mathrm{~m}$, average annual rainfall $\approx 800 \mathrm{~mm}$ ). Fruit from three different orchard blocks were mixed within each block and defect-free fruit were packed in wooden boxes (70 fruit per box) with standard perforated polyethylene liners. Forty-five boxes of the packed fruit (15 boxes of each block) were immediately cooled in a room at $-1.1^{\circ} \mathrm{C}$. After $24 \mathrm{~h}, 15$ boxes (five boxes of each block) were exposed to $0.15 \mu \mathrm{L} \cdot \mathrm{L}^{-1}$ and the other 15 boxes (five boxes of each block) to $0.3 \mu \mathrm{L} \cdot \mathrm{L}^{-1}$ 1-MCP (SmartFresh ${ }^{\circledR}$; AgroFresh, Spring House, PA) in an airtight room $\left(39.75 \mathrm{~m}^{3}\right)$ at $0{ }^{\circ} \mathrm{C}$ for $24 \mathrm{~h}$ according to the application procedures recommended by the manufacturer. The remaining 15 boxes (five boxes of each block) without 1-MCP treatment was the control. After 1-MCP fumigation, all the fruit were stored in air at $-1.1{ }^{\circ} \mathrm{C}( \pm 0.5)$ and $>95 \%$ relative humidity for 8 months. Every other month during storage, three boxes of fruit (one box of each block), representing three replications of each treatment, were removed from storage for physiological, biochemical, and quality evaluations.

INTERNAL ETHYLENE CONCENTRATION, EPR, AND RR. Internal ethylene concentration (IEC) was measured on fruit immediately on removal from cold storage. Gas was sampled from five individual fruit per treatment replication using a vacuumimmersion technique (Chen and Mellenthin, 1981), and injected into a gas chromatograph (GC-8A; Shimadzu, Kyoto, Japan). Nitrogen was used as the carrier gas at a flow rate of $50 \mathrm{~mL} \cdot \mathrm{min}^{-1}$. The injector and detector port temperatures were 90 and $140^{\circ} \mathrm{C}$, respectively. An external standard of ethylene $\left(1.0 \mu \mathrm{L} \cdot \mathrm{L}^{-1}\right)$ was used for calibration. EPR and RR were determined from a sample of five fruit per replicate on day 1 at $20^{\circ} \mathrm{C}$ after removal from cold storage. The fruit were placed in a 3.8-L airtight jar for $1 \mathrm{~h}$. Gas samples were withdrawn through a septum using a 1-mL gas-tight syringe. Ethylene was measured by gas chromatography as described above and EPR was expressed as microliters per kilogram per hour. The headspace $\mathrm{CO}_{2}$ concentration was measured using a $\mathrm{CO}_{2}$ analyzer (model 900161; Bridge Analyzers, Alameda, CA). Fruit RR was expressed as milliliters of $\mathrm{CO}_{2}$ per kilogram per hour.

Fruit PeEl COLOR ANd CHLOROPhyll CONTENT. Fruit peel greenish color was visually evaluated on 10 fruit in each replicate on day 1 at $20{ }^{\circ} \mathrm{C}$ after removal from cold storage based on a scale of 5 to 1 , where $5=$ green, $3=$ turning from green to yellow, and $1=$ yellow. For chlorophyll content, 20 peel discs $\left(1 \mathrm{~cm}^{2}\right.$ each) of 10 fruit in each replicate were immersed in $15 \mathrm{~mL}$ of $80 \%(\mathrm{v} / \mathrm{v})$ acetone in a covered beaker. The beakers with peel tissue and acetone were shaken with an orbital shaker (VCOS-4P; PRO Scientific, Oxford, CT) at $120 \mathrm{rpm}$ and $20^{\circ} \mathrm{C}$ for $24 \mathrm{~h}$ in the dark. After extraction, the solvent was centrifuged at $11,550 g_{n}$ for $5 \mathrm{~min}$ and absorbance was read at 645 and 663 $\mathrm{nm}$ on a spectrophotometer (model Ultrospec 3100 pro; Biochrom, Cambridge, England). The content of chlorophyll $a+b$ was calculated according to Arnon's Equations (Arnon, 1949) and expressed as microgram per gram of fresh weight.

DeCAY, FF, SOLUble SOLID CONTENT, TA, AND RIPENING CAPACITY. Decay was counted on day 1 at $20{ }^{\circ} \mathrm{C}$ after removal from cold storage. Any visible pathological lesion was considered as decay and expressed as percentage of incidence. FF was measured on 10 fruit per replication on day 1 at $20^{\circ} \mathrm{C}$ using a fruit texture analyzer (model GS-14; Guss Manufacturing, Strand, South Africa) with an $8-\mathrm{mm}$ probe that penetrates $9 \mathrm{~mm}$ in $0.9 \mathrm{~s}$. Two measurements were obtained per fruit on opposite sides of the equatorial region after removal of 20-mm-diameter peel discs. After FF determination, $100 \mathrm{~g}$ of flesh tissue was ground for $3 \mathrm{~min}$ in a juice extractor (model 6001; Acme Juicer Manufacturing Co., Sierra Madre, CA) equipped with a uniform strip of milk filter (Schwartz Manufacturing Co., Two Rivers, WI). Soluble solid content (SSC) of the juice was determined using a digital refractometer (Atago, Tokyo, Japan). TA was determined by titrating $10 \mathrm{~mL}$ of the juice to an endpoint $\mathrm{pH} 8.1$ using $0.1 \mathrm{~N} \mathrm{NaOH}$ with a commercial titration system (model T80/20; Schott-Gerate, Hofheim, Germany) and expressed as percentage (grams per $100 \mathrm{~mL}$ juice) of malic acid equivalents. Ripening capacity was determined as competency of fruit softening; 10 fruit of each replicate were ripened for $7 \mathrm{~d}$ at $20{ }^{\circ} \mathrm{C}$ and $\mathrm{FF}$ was determined as described above. 
RNA EXTRACTION, ISOLATION OF CDNA, AND REAL-TIME QUANTITATIVE POLYMERASE ChaIN REACTION. Peel tissue, including the epidermis and 2 to $3 \mathrm{~mm}$ of hypodermal cortex, was excised with a fruit peeler from the equatorial region of 10 fruit from each replication and immediately frozen in liquid nitrogen. The peel tissue samples were stored at $-80{ }^{\circ} \mathrm{C}$ until used for extraction of RNA. For RNA isolation, 1 to $2 \mathrm{~g}$ of frozen pear peel was ground to a powder in liquid nitrogen, and total RNA was isolated using a Plant Total RNA Kit (Sigma-Aldrich, St. Louis, MO) as specified by the manufacturer. First-strand cDNA was performed from $1 \mu \mathrm{g}$ total RNA using Invitrogen's Superscript ${ }^{\mathrm{TM}}$ III First Strand Synthesis Systems for real-time quantitative polymerase chain reaction (RT-qPCR) Systems (Thermo Fisher Scientific, Waltham, MA) using oligo (dT) as primers. Reactions for RT-qPCR on the cDNA were performed with iTaq $^{\mathrm{TM}}$ Universal SYBR Green Supermix (Bio-Rad, Hercules, CA). The amplification protocol consisted of an initial step at $95{ }^{\circ} \mathrm{C}$ for $2 \mathrm{~min}$, and 40 cycles at $95^{\circ} \mathrm{C}$ for $10 \mathrm{~s}$ then $60^{\circ} \mathrm{C}$ for $30 \mathrm{~s}$. The specificity of the RT-qPCR amplification was checked routinely by melting curve analysis. Data were analyzed using the $2^{-\Delta \Delta \mathrm{Ct}}$ method (Livak and Schmittgen, 2001) and are presented as the relative level of gene expression. Transcript levels of ethylene biosynthesis and perception genes and chlorophyll degradation genes were analyzed using PcActin (El-Sharkawy et al., 2003) as an internal control. Sequences for primers were designed according to previous research (Chiriboga et al., 2013; El-Sharkawy et al., 2003, 2004; Fonseca et al., 2005; Villalobos-Acuña et al., 2011) and are presented in Table 1.

STATISTICAL ANALYSES. There were three replications (orchard blocks) per treatment at each evaluation period. The experimental design was completely randomized and data were subjected to analysis of variance (ANOVA) using Statistica version $6\left(\right.$ StatSoft $^{\circledR}$, Tulsa, OK). When appropriate, means were separated by Fisher's protected least significant difference test at $P<0.05$. The percentages of decay, SSC, and TA were arcsin square root transformed before analysis.

\section{Results}

IEC, EPR, AND RR. In control fruit, IEC accumulated and reached a peak at 6 months and decreased thereafter (Fig. 1A). EPR in control fruit increased significantly after 2 months, reached a maximum value after 4 months, and maintained at a high level thereafter (Fig. 1B). 1-MCP inhibited IEC and EPR. The fruit treated with 1-MCP at $0.15 \mu \mathrm{L} \cdot \mathrm{L}^{-1}$ started to produce ethylene at a low rate after 6 months and had $21.7 \%$ of the EPR of the control fruit at 8 months storage. The fruit treated with $1-\mathrm{MCP}$ at $0.3 \mu \mathrm{L} \cdot \mathrm{L}^{-1}$ did not produce ethylene until 8 months and had only $4.8 \%$ EPR of the control fruit at 8 months storage. RR of the control fruit increased significantly after 2 months, reached a maximum value after 4 months, and decreased thereafter (Fig. 1C). 1-MCP reduced RR during 8 months storage. RR of the fruit treated with 1-MCP increased after 2 months and maintained relatively unchanged thereafter. There was no significant difference in RR between $1-\mathrm{MCP}$ at 0.15 and 0.3 $\mu \mathrm{L} \cdot \mathrm{L}^{-1}$ throughout storage.

Chlorophyll degradation. Both of fruit peel chlorophyll content and sensory peel green color rating decreased gradually during storage (Fig. 2A and B). In the control fruit, peel color turned visibly yellowish at 6 months (Fig. 3), peel chlorophyll content degraded $55.1 \%$ and $68.4 \%$ of the initial value after 6 and 8 months storage, respectively. 1-MCP impeded chlorophyll degradation and color change. After 8 months, peel 

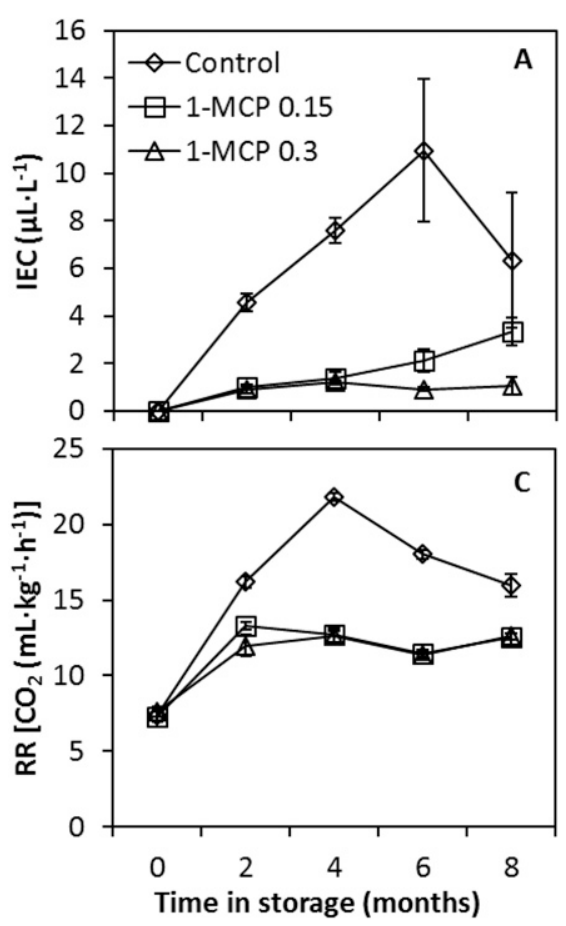

Fig. 1. (A) Internal ethylene concentration (IEC), (B) ethylene production rate (EPR), and (C) respiration rate (RR) of 'Bosc' pears influenced by 1-methylcyclopropene (1-MCP) treatments $\left(0.15,0.3 \mu \mathrm{L} \cdot \mathrm{L}^{-1}\right)$ during 8 months of storage at $-1.1^{\circ} \mathrm{C}$. Values are mean $\pm \mathrm{SD}(\mathrm{n}=3)$.
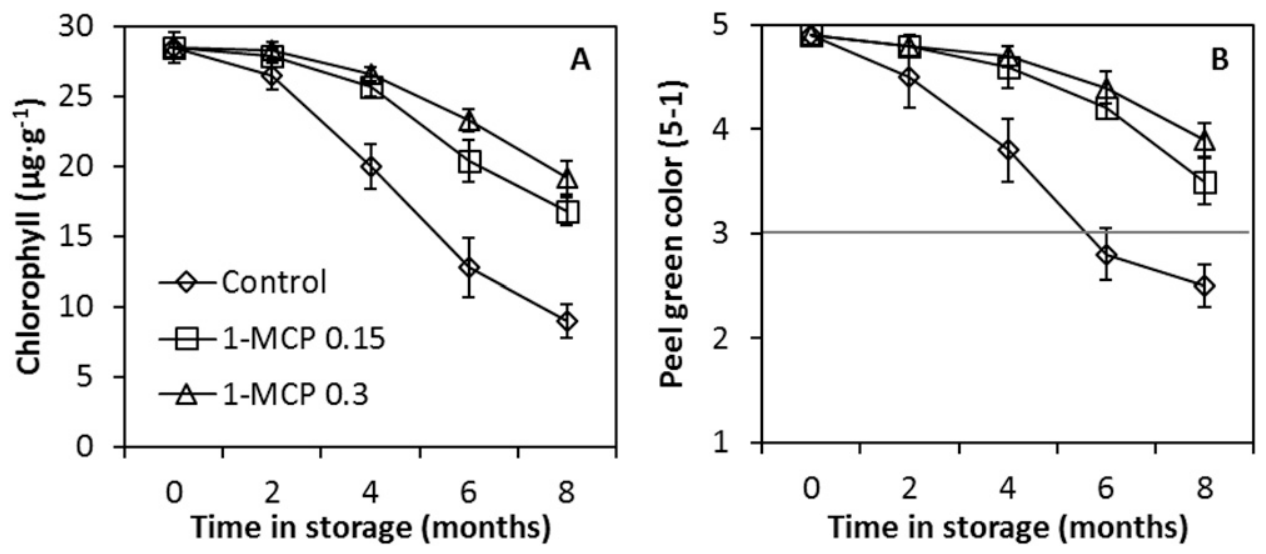

Fig. 2. (A) Fruit peel chlorophyll content and (B) green color rating of 'Bosc' pears influenced by 1-methylcyclopropene $(1-\mathrm{MCP})$ treatments $\left(0.15,0.3 \mu \mathrm{L} \cdot \mathrm{L}^{-1}\right)$ during 8 months of storage at $-1.1{ }^{\circ} \mathrm{C}$. Color scale of $5-1(5=$ green, $3=$ turning from green to yellow, $1=$ yellow $)$. Values are mean $\pm \mathrm{SD}(\mathrm{n}=3)$. chlorophyll content lost $41.0 \%$ and $32.6 \%$ in fruit treated with $1-\mathrm{MCP}$ at 0.15 and $0.3 \mu \mathrm{L} \cdot \mathrm{L}^{-1}$, respectively.

F F， S S C， T A， R I P E I N G CAPACITY, AND DECAY. Fruit firmness decreased gradually during cold storage and 1-MCP treatment had no significant effect on the decline in FF during 8 months storage (Fig. 4A). SSC increased slightly during storage though 1-MCP had no influence on SSC during 8 months storage (Fig. 4B). TA declined in control fruit by $35.0 \%$; $1-\mathrm{MCP}$ at 0.15 and $0.3 \mu \mathrm{L} \cdot \mathrm{L}^{-1}$ maintained $15.0 \%$ higher TA than the control fruit at the end of the storage period (Fig. 4C). The control fruit developed ripening capacity after 2 months with FF of $13.8 \mathrm{~N}$ when exposed to $20^{\circ} \mathrm{C}$ for $7 \mathrm{~d}$ at 2 months, but fruit treated with 1-MCP did not develop ripening capacity throughout the 8 months storage period (Fig. 4D). The control fruit developed $1.3 \%, 5.8 \%$, and $8.8 \%$ decay after 4, 6, and 8 months storage, respectively (Fig. 4E). Fruit treated with $1-\mathrm{MCP}$ at 0.15 and $0.3 \mu \mathrm{L} \cdot \mathrm{L}^{-1}$ developed $3.6 \%$ and $2.1 \%$ decay, respectively, after 8 months storage.

EXPRESSION OF ETHYLENE BIOSYNTHESIS AND PERCEPTION GENES. The ethylene synthesis genes PcACS1, PcACS2, PcACS4, $P C A C S 5$, and $P C A C O 1$ were characterized [Fig. 5 (left column)]. In control fruit, the transcription of PCACS1, PCACS4, PCACS5, and $P C A C O 1$ increased gradually and reached the peaks at $6,6,6$, and 4 months storage, and decreased or remained relatively unchanged thereafter. In contrast, the transcription level of PCACS2 declined during 8 months of cold storage. With a dose response, 1-MCP inhibited the expression of $P C A C S 1, P C A C S 4$, $P C A C S 5$, and $P C A C O 1$, and delayed the transcription peaks. 1MCP at $0.3 \mu \mathrm{L} \cdot \mathrm{L}^{-1}$ totally inhibited the expression of PcACS4 and $P C A C O 1$ for 8 months storage. In contrast, the expression of PCACS 2 was upregulated by $1-\mathrm{MCP}$ during storage, but displayed little difference between the 1-MCP treated and control fruit at the end of storage.

The ethylene receptor genes PcETR1, PcETR2, PcETR5, $P c C T R 1$, and PcERS1 were also analyzed [Fig. 5 (right column)]. In control fruit, the expression of PCETR1, PcETR2, and PCERS1 increased and peaked at 6,8 , and 4 months, respectively. In contrast, the transcript level of PcETR5 and PCCTR1 decreased during cold storage period. With a dose response, 1-MCP downregulated the expression of PcETR1, PcETR2, and PcERS1. 1MCP did not influence the expression of PCETR5 and PCCTR1.
Fig. 3. Appearance of 'Bosc' pears influenced by 1-methylcyclopropene (1-MCP) treatments $\left(0.15,0.3 \mu \mathrm{L} \cdot \mathrm{L}^{-1}\right)$ after 6 months of storage at $-1.1^{\circ} \mathrm{C}$. 

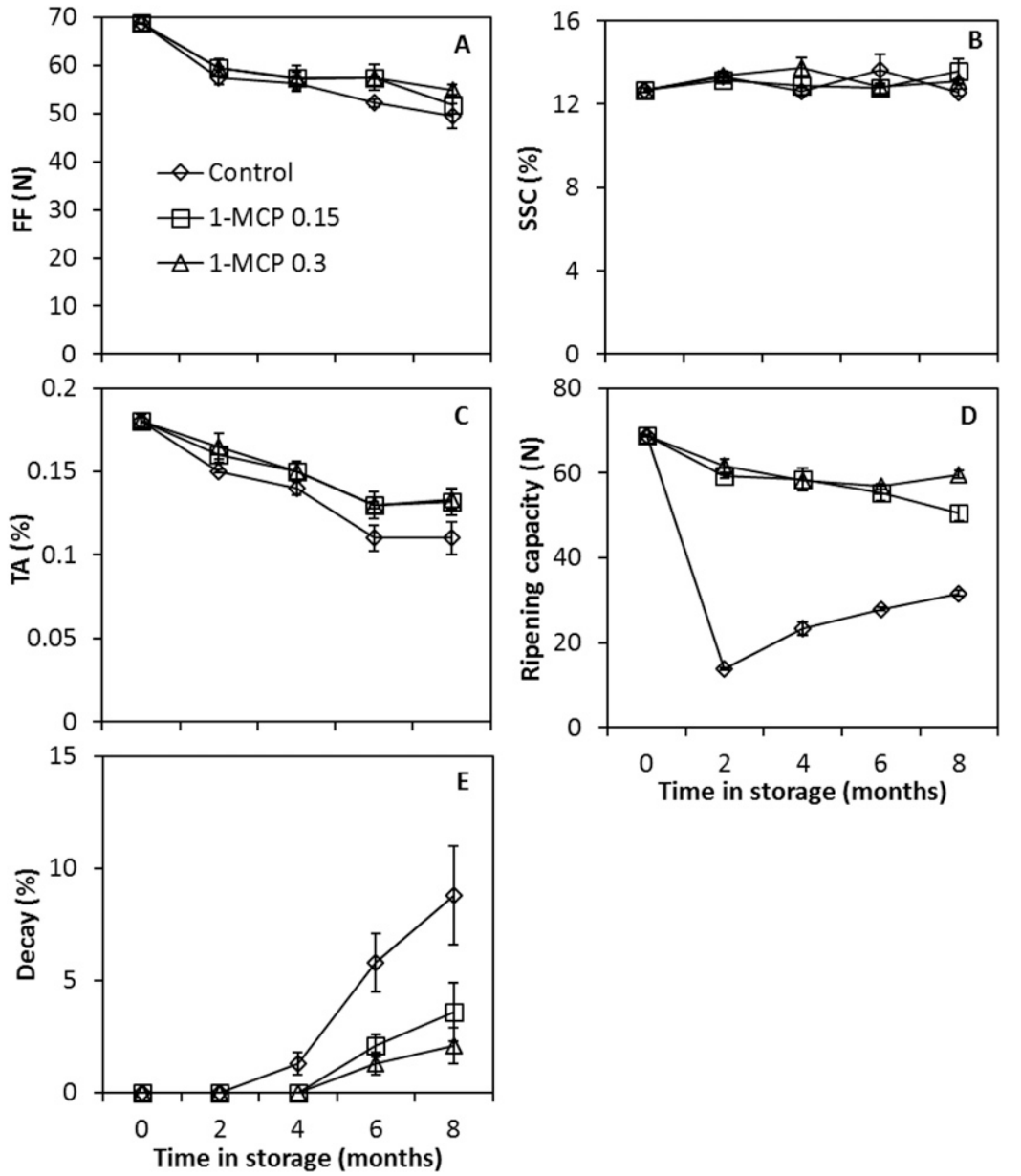

Fig. 4. Fruit (A) flesh firmness (FF), (B) soluble solid content (SSC), (C) titratable acidity (TA), ripening capacity expressed as $\mathrm{FF}$ after (D) $7 \mathrm{~d}$ at $20^{\circ} \mathrm{C}$, and (E) decay of 'Bosc' pears influenced by 1 -methylcyclopropene (1-MCP) treatments $\left(0.15,0.3 \mu \mathrm{L} \cdot \mathrm{L}^{-1}\right)$ during 8 months of storage at $-1.1{ }^{\circ} \mathrm{C}$. Values are mean $\pm S D(n=3)$.

EXPRESSION OF CHLOROPHYLL DEGRADATION GENES. Chlorophyll degradation genes $P C P P H, P c N O L, P c S G R, P c R C C R$, $P C N Y C, P C C H L$, and $P C P A O$ were characterized during 8 months storage (Fig. 6). In control fruit, the expression of $P C P P H, P C N O L, P C S G R, P C R C C R$, and PCNYC increased about 60-, 56-, 216-, 228-, and 10-fold, respectively, during $2-4$ months of storage and decreased thereafter. The expression of $P C P A O$ increased gradually and reached its highest level at 6 months and decreased thereafter. In contrast, the transcription level of $P c C H L$ declined during 8 months storage.

1-MCP inhibited the expression of $P c P P H, P c N O L, P c S G R$, $P c R C C R, P c N Y C$, and $P C P A O$; for example, the expression at their peak stages was only $64.3 \%, 64.4 \%, 31.0 \%, 83.5 \%$, $10.0 \%$, and $38.8 \%$, respectively, in fruit treated with $1-\mathrm{MCP}$ at $0.15 \mu \mathrm{L} \cdot \mathrm{L}^{-1}$ than the control fruit. The expression of $P c P P H$, $P c N O L, P C R C C R$, and $P C P A O$, but not $P C S G R$ and $P c N Y C$, had a dose response to 1-MCP. 1-MCP had no consistent effect on the expression of $\mathrm{PcCHL}$.

\section{Discussion}

The short storage life of european pears is associated with EPR occurring during cold storage (Villalobos-Acuña et al., 2011; Xie et al., 2015). In this study, the control 'Bosc' pear fruit exhibited a significant increase in IEC and EPR during 8 months cold storage. 1MCP which inhibited ethylene biosynthesis, slowed down RR and the losses of FF, TA and green color, reduced decay, and therefore prolonged 'Bosc' pear storage life. At the same time, however, 1-MCP inhibited fruit ripening capacity at room temperature after cold storage. In climacteric fruit, 1-MCP inhibits ethylene function and synthesis by competing for the binding site of ethylene receptors which is an irreversible process once a high enough dose of 1-MCP occupies the ethylene binding receptors (Blankenship and Dole, 2003). Plant tissues have been shown to vary widely in their ability to regenerate new ethylene receptors (Blankenship and Dole, 2003). 1-MCP at 0.15 or $0.3 \mu \mathrm{L} \cdot \mathrm{L}^{-1}$ might totally shut down the formation of new binding receptors in 'Bosc' pear fruit when stored at $-1{ }^{\circ} \mathrm{C}$ for 8 months. How to recover ripening capacity of the 1-MCP treated european pears after cold storage warrants future research.

ETHYLENE BIOSYNTHESIS. Ethylene in fruit is biosynthesized from methionine and there are two key steps in ethylene biosynthesis: the conversion of s-adenosylmethionine to 1aminocyclopropene-1-carboxylic acid (ACC) via ACC synthase (ACS) and the subsequent conversion of ACC to ethylene via ACC oxidase (ACO) (Adams and Yang, 1979). Both steps were highly transcriptionally regulated by multigene families in tomatoes [Solanum lycopersicum (Barry and Giovannoni, 2007)] and 'Conference' european pears (Chiriboga et al., 2013). Four ACS genes and one ACO gene have been found and described in european pears during development and ripening (El-Sharkawy et al., 2004; Xie et al., 2014, 2015). In this study, PcACS1, PCACS4, PCACS5, and PCACO1 increased their expression dramatically coincident with ethylene synthesis in the control fruit during cold storage, which is in agreement with previous reports for european pears; i.e., 'Bartlett' (Villalobos-Acuña et al., 2011), 'Anjou' (Xie et al., 2014), and 'Starkrimson' (Xie et al., 2015). In contrast, $P C A C S 2$ was not induced by chilling in 'Bosc', a result which agrees with that reported for 'Bartlett' (Villalobos-Acuña et al., 2011) and 'Anjou' pears (Xie et al., 2014) but differs from 'Starkrimson' pears (Xie et al., 2015) whereby PCACS2 expression increased during cold storage. El-Sharkawy et al. (2004) reported that the expression of $P C A C S 2$ in responding to ethylene treatment differently in an early season pear cultivar Old-Home and a late-season cultivar Passe-Crassane; positively and negatively, respectively. Thus, the disparate responses of PcACS2 in different pear cultivars indicate a genotypic effect and the function of $P C A C S 2$ in the ripening process remains unclear. 1-MCP significantly reduced the transcription levels of PCACS1, PCACS4, PCACS5, and PCACO1, resulting in lower EPR and $\mathrm{RR}$ in 'Bosc' pear during storage. These findings are generally consistent with previous reports that ethylene synthesis genes are inhibited by 1-MCP in european pears (El-Sharkawy et al., 

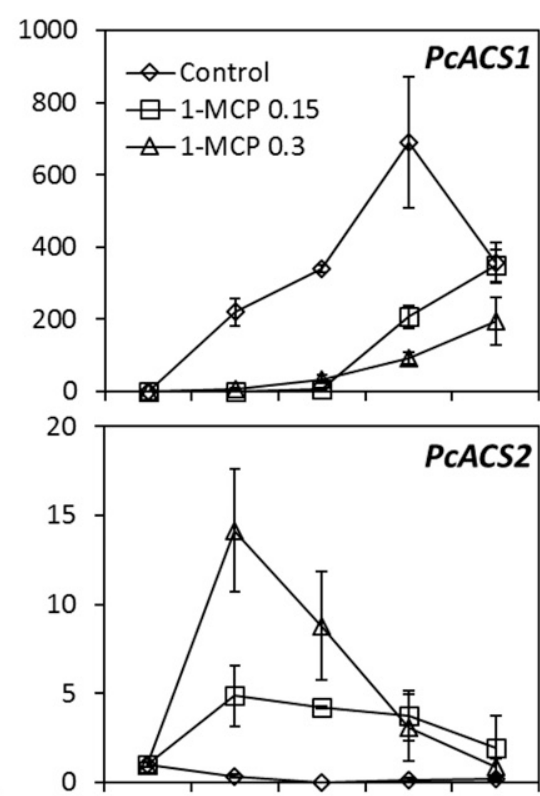

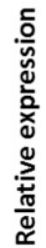
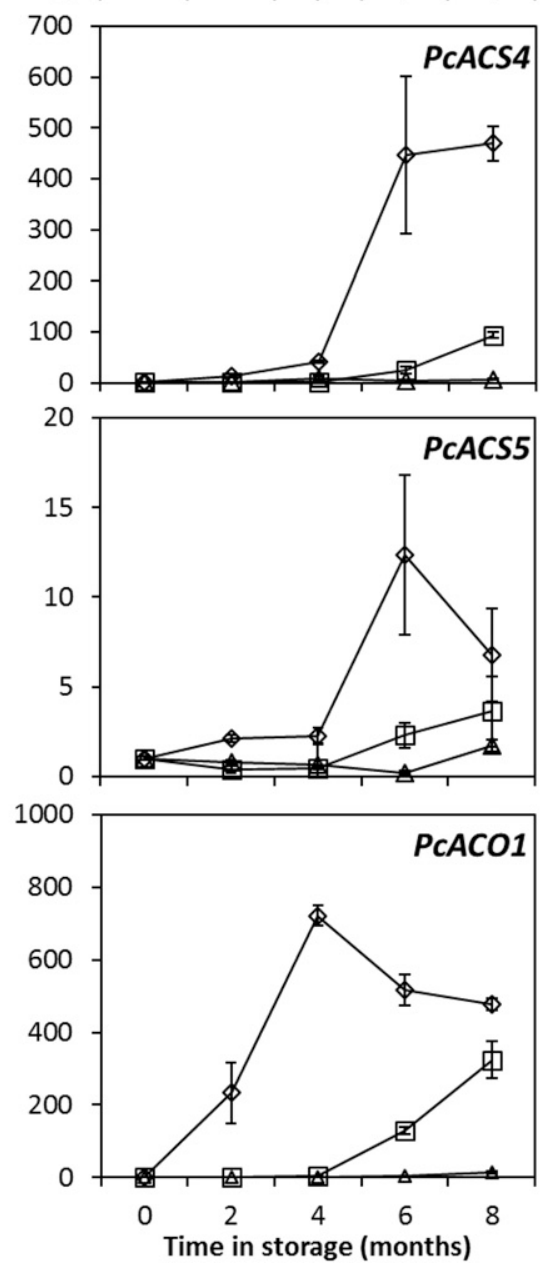
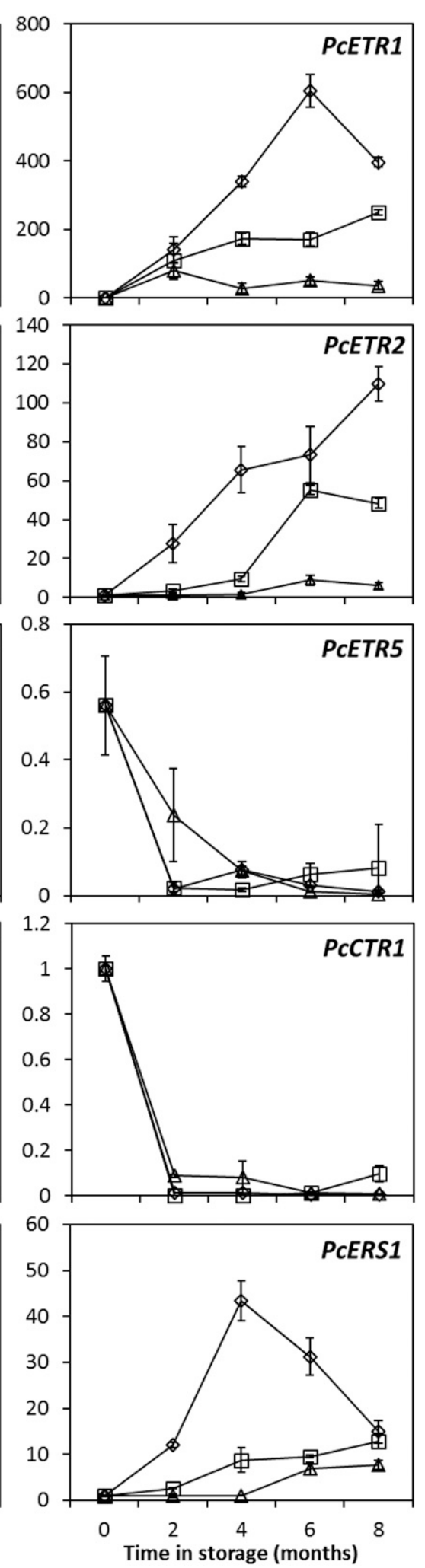

Fig. 5. Transcription levels of ethylene biosynthesis genes (PcACS1, PcACS2, PcACS4, PcACS5, and PCACO1) and ethylene receptor genes (PcETR1, PcETR2, PcETR5, PcCTR1, and PcERS1) of 'Bosc' pears influenced by 1 -methylcyclopropene $(1-\mathrm{MCP})$ treatments $\left(0.15,0.3 \mu \mathrm{L} \cdot \mathrm{L}^{-1}\right)$ during 8 months of storage at $-1.1^{\circ} \mathrm{C}$. Values are mean $\pm \mathrm{SD}(\mathrm{n}=3)$.

2004; Villalobos-Acuña et al., 2011; Xie et al., 2014, 2015). There are two ethylene synthesis regulation systems in climacteric fruit: system-1 and system-2 (Lelièvre et al., 1997). In

tomato, system-1 ethylene synthesis is regulated via LeACSIA and LeACS6, and system2 is subsequently initiated and maintained by ethylene-dependent induction of LeACS2 (Barry et al., 2000). In this study, IEC and EPR are correlated with increased PcACSI, PCACS4, and PCACS5 and decreased $P c A C S 2$ expression in 'Bosc' pear fruit during cold storage. PCACS1, PCACS4, and $P C A C S 5$ in pear fruit behaved in a similar fashion to LeACS2 in tomato, and PcACS2 similar to LeACS1A and LeACS6. This suggests that $P C A C S 2$, in pear fruit, may regulate system-1 synthesis and its expression is inhibited by internal ethylene; whereas $P C A C S 1, P C A C S 4$, and PCACS5 may regulate system-2 and their expressions are induced by internal ethylene.

Chlorophyll degradation. Chlorophyll degradation is an indication of fruit ripening and senescence. CHL is the first enzyme in a multistep enzymatic process of chlorophyll degradation. In the present study, the transcription level of PcCHL1 was not upregulated, which is not supported by the chlorophyll degradation pattern; 1-MCP inhibited chlorophyll degradation but did not affect the expression of PcCHL1 in 'Bosc' pear during storage. These results are consistent with the report on asian pear (Cheng and Guan, 2014). In fact, HarpazSaad et al. (2007) reported that CHL is a ratelimiting enzyme in chlorophyll catabolism via posttranslational regulation in squash (Cucurbita pepo). It is agreed in broccoli (Brassica oleracea var. italica) that BoCLH1 expression is negatively regulated during senescence and does not respond to hormonal regulation (Gomez-Lobato et al., 2012). However, in the nonclimacteric fruit lemon (Citrus limon), chlorophyll degradation and $\mathrm{ClCHL}$ expression are concomitantly increased by exogenous ethylene indicating that $C l C H L$ may play a role in chlorophyll breakdown in the fruit (Jacob-Wilk et al., 1999; Shemer et al., 2008). This suggests that the role of $C H L$ may differ among species.

$\mathrm{PPH}$ and PAO are important enzymes in senescence-induced chlorophyll degradation (Gomez-Lobato et al., 2012; Hortensteiner, 2006). In this work, the expression of $P c P P H$ in control fruit greatly increased after 2 months and then decreased thereafter; 1MCP inhibited its expression significantly. $P c P A O$ expression increased until 6 months and then decreased at 8 months in control fruit while 1-MCP inhibited its expression to a low level throughout the storage period. Thus the expression patterns of $P C P P H$ and $P C P A O$ are closely correlated with the degradation of chlorophyll in 'Bosc' pear during storage. These results are consistent with those found in asian pear (Cheng and Guan, 2014). PPH 

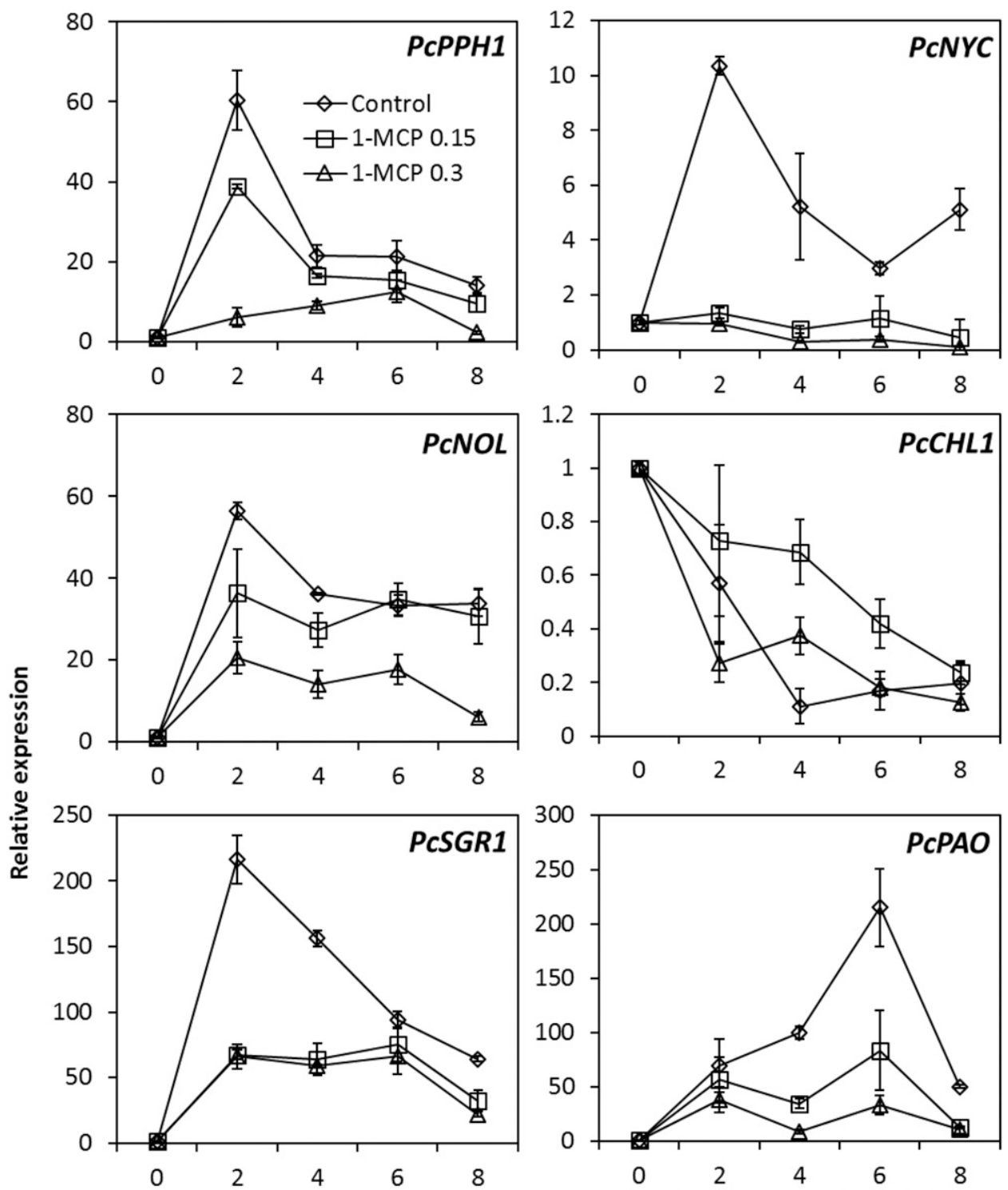
$P b N Y C$, and $P b S G R$ increased until $30 \mathrm{~d}$ of storage, and then they declined in control fruit; 1-MCP reduced the gene's expression (Cheng et al., 2012). These results suggest that $P c P P H, P c P A O, P c N Y C$, and $P c S G R$ play an important role in chlorophyll degradation of 'Bosc' pears during cold storage.

The expression of $P C R C C R$ greatly increased in the control fruit after 2 months and maintained high level until 8 months; 1-MCP reduced its expression after 4 months of storage. It is interesting that $P b R C C R$ was not upregulated in asian pears during storage with chlorophyll breakdown nor was it responsive to $1-\mathrm{MCP}$ treatment (Cheng et al., 2012; Cheng and Guan, 2014). Thus, the role of $R C C R$ on chlorophyll degradation may differ among species of pear.

ETHYLENE PERCEPTION AND CHLOROPHYLL DEGRADATION. Ethylene signaling receptors play a critical role in fruit ripening and senescence (Chervin and Deluc, 2010; John-Karuppiah and Burns, 2010). Five ethylene perceptionrelated genes including four receptor genes (PcETR1, PcETR2, PcETR5, and PCERS1) and a PcCTRl-like gene have been identified in european pears (El-Sharkawy et al., 2003) and they were analyzed in this study. Results indicated that the transcription of PcETR1, PcETR2, and PCERS1 generally increased on ripening in control fruit and they were inhibited by 1-MCP treatment during storage, which coincided with ethylene production and chlorophyll breakdown in 'Bosc' pears during storage. PCETR 5 and $P c C T R 1$ were downregulated during

Fig. 6. Transcription levels of chlorophyll degradation genes (PcPPH1, PcNOL, PcASGR1, PcRCCR, PcNYC, $P c C H L 1$, and $P c P A O)$ of 'Bosc' pears influenced by 1-methylcyclopropene (1-MCP) treatments $(0.15,0.3$ $\left.\mu \mathrm{L} \cdot \mathrm{L}^{-1}\right)$ during 8 months of storage at $-1.1^{\circ} \mathrm{C}$. Values are mean $\pm \operatorname{SD}(\mathrm{n}=3)$.

was proposed to be an important gene in chlorophyll breakdown in arabidopsis (Arabidopsis thaliana) during senescence and a pph mutant was unable to degrade chlorophyll during senescence (Schelbert et al., 2009). PAO was reported to be storage and unaffected by 1-MCP treatment in 'Bosc' pears. These results are similar to our previous findings in a study on 'Anjou' pears (Xie et al., 2014). Moreover, the expression of PCETR1, PCETR2, and PCERS1 was correlated with the 
expression of chlorophyll degradation genes $P C P P H, P c P A O$, $P c N Y C$, and PcSGR (Figs. 5 and 6). In asian pears, Cheng and Guan (2014) reported that the mRNA levels of PbERS1, PbERS2, PbETR1, and PbETR2 significantly increased during fruit degreening and ripening were correlated with the expression patterns of $P b P P H, P b P A O$, and $P b S G R 1$. Similar results were showed in apples [Malus domestica (Yang et al., 2013)] in that MdETR1, MdETR2, MdETR5, and MdERSs transcription levels increased during ripening and were decreased with 1MCP treatment. In different species, transgenic plants that lack ethylene binding ability and exhibit SGR phenotypes (Narumi et al., 2005; Nukui et al., 2004; Yang et al., 2008).

In conclusion, 'Bosc' pears are highly sensitive to 1-MCP with respect to ethylene production, retarding yellowing, and extending storage quality. The genes of $P C P P H, P c P A O$, $P c N Y C$, and $P c S G R$ are involved in the chlorophyll degradation of 'Bosc' pear fruit. Ethylene signaling may play an important role in regulating the expression of chlorophyll degradation associated genes.

\section{Literature Cited}

Adams, D.O. and S.F. Yang. 1979. Ethylene biosynthesis: Identification of 1-aminocyclopropane-1-carboxylic acid as an intermediate in the conversion of methionine to ethylene. Proc. Natl. Acad. Sci. USA 76:170-174.

Amir-Shapira, D., E.E. Goldschmidt, and A. Altman. 1987. Chlorophyll catabolism in senescing plant tissues: In vivo breakdown intermediates suggest different degradative pathways for citrus fruit and parsley leaves. Proc. Natl. Acad. Sci. USA 84:1901-1905.

Argenta, L.C., X.T. Fan, and J.P. Mattheis. 2003. Influence of 1-methylcyclopropene on ripening, storage life, and volatile production by 'd'Anjou cv. pear fruit. J. Agr. Food Chem. 51:38583864.

Arnon, D.I. 1949. Copper enzymes in isolated chloroplasts: Polyphenoloxidase in Beta vulgaris. Plant Physiol. 241:1-15.

Barry, C.S. and J.J. Giovannoni. 2007. Ethylene and fruit ripening. J. Plant Growth Regulat. 26:143-159.

Barry, C.S., M.I. Llop-Tous, and D. Grierson. 2000. The regulation of 1-aminocyclopropane-1-carboxylic acid synthase gene expression during the transition from system-1 to system-2 ethylene synthesis in tomato. Plant Physiol. 123:979-986.

Blankenship, S.M. and J.M. Dole. 2003. 1-Methylcyclopropene, a review. Postharvest Biol. Technol. 28:1-25.

Charoenchongsuk, N., K. Ikeda, A. Itai, A. Oikawa, and H. Murayama. 2015. Comparison of the expression of chlorophyll-degradationrelated genes during ripening between stay-green and yellow-pear cultivars. Sci. Hort. 181:89-94.

Chen, P.M. 2004. Pear. In: K.C. Gross, C.Y. Wang, and M. Saltveit (eds.). The commercial storage of fruits, vegetables, and florist and nursery crops. U.S. Dept. Agr., Agr. Res. Serv., Agr. Hdbk. 66. 6 June 2016. <http://www.ba.ars.usda.gov/hb66/107pear.pdf $>$.

Chen, P.M. and W.M. Mellenthin. 1981. Effects of harvest date on ripening capacity and postharvest life of 'd'Anjou' pears. J. Amer. Soc. Hort. Sci. 106:38-42.

Chen, P.M., W.M. Mellenthin, and S.B. Kelly. 1983. Fruit quality of 'Bosc' pears stored in air or one percent oxygen as influenced by maturity. Sci. Hort. 21:45-52.

Chen, P.M., D.G. Richardson, and W.M. Mellenthin. 1982. Differences in biochemical composition between 'Beurre d'Anjou' and 'Bosc' pears during fruit development and storage. J. Amer. Soc. Hort. Sci. 107:807-812.

Chen, S., M. Zhang, and S. Wang. 2009. Physiological and quality responses of chinese 'Suli' pear (Pyrus bretschneideri Rehd.) to 1-MCP vacuum infiltration treatment. J. Sci. Food Agr. 90:13171322.
Cheng, Y. and J. Guan. 2014. Involvement of pheophytinase in ethylene-mediated chlorophyll degradation in the peel of harvested 'Yali' pear. J. Plant Growth Regulat. 33:364-372.

Cheng, Y., Y. Dong, H. Yan, W. Ge, C. Shen, J. Guan, L. Liu, and Y. Zhang. 2012. Effect of 1-MCP on chlorophyll degradation pathwayassociated genes expression and chloroplast ultrastructure during the peel yellowing of Chinese pear fruits in storage. Food Chem. 135:415-422.

Chervin, C. and L. Deluc. 2010. Ethylene signaling receptors and transcription factors over the grape berry development: Gene expression profiling. Vitis 49:129-136.

Chiriboga, M., M. Saladie, J. Bordonaba, I. Recasens, J. Garcia-Mas, and C. Larrigaudiere. 2013. Effect of cold storage and 1-MCP treatment on ethylene perception, signaling and synthesis: Influence on the development of the evergreen behavior in 'Conference' pears. Postharvest Biol. Technol. 86:212-220.

El-Sharkawy, I., B. Jones, L. Gentzbittel, J.M. Lelievre, J.C. Pech, and A. Latché. 2004. Differential regulation of ACC synthase genes in cold-dependent and independent ripening in pear fruit. Plant Cell Environ. 27:1197-1210.

El-Sharkawy, I., B. Jones, Z.G. Li, J.M. Lelièvre, J.C. Pech, and A. Latché. 2003. Isolation and characterization of four ethylene perception elements and their expression during ripening in pears (Pyrus communis L.) with/without cold requirement. J. Expt. Bot. 54:1615-1625.

Fonseca, S., L. Monteiro, M.G. Barreiro, and M.S. Pais. 2005. Expression of genes encoding cell wall modifying enzymes is induced by cold storage and reflects changes in pear fruit texture. J. Expt. Bot. 56:2029-2039.

Gomez-Lobato, M., J. Hasperue, A. Chaves, and G. Martinez. 2012. Effect of 1-MCP on the expression of chlorophyll degrading genes during senescence of broccoli (Brassica oleracea L.). Sci. Hort. 144:208-211.

Gong, Y. and J.P. Mattheis. 2003. Effect of ethylene and 1methylcyclopropene on chlorophyll catabolism of broccoli florets. Plant Growth Regulat. 40:33-38.

Harpaz-Saad, S., T. Azoulay, T. Arazi, E. Benyaakov, A. Mett, Y. Mosheshiboleth, S. Hortensteiner, D. Gidoni, A. Galon, E. Egoldschmidt, and Y. Eyal. 2007. Chlorophyllase is a rate-limiting enzyme in chlorophyll catabolism and is posttranslationally regulated. Plant Cell 19:1007-1022.

Hortensteiner, S. 2006. Chlorophyll degradation during senescence. Annu. Rev. Plant Biol. 57:55-77.

Hortensteiner, S., K.L. Wuthrich, P. Matile, K.H. Ongania, and B. Krautler. 1998. The key step in chlorophyll breakdown in higher plants: Cleavage of pheophorbide a macrocycle by a monooxygenase. J. Biol. Chem. 273:15335-15339.

Jacob-Wilk, D., D. Holland, E.E. Goldschmidt, J. Riov, and Y. Eyal. 1999. Chlorophyll breakdown by chlorophyllase: Isolation and functional expression of the Chlase 1 gene from ethylene-treated citrus fruit and its regulation during development. Plant J. 20:653-661.

Jiang, H., M. Li, N. Liang, H. Yan, Y. Wei, X. Xu, J. Liu, Z. Xu, F. Chen, and $\mathrm{G}$. Wu. 2007. Molecular cloning and function analysis of the stay green gene in rice. Plant J. 52:197-209.

John-Karuppiah, K.J. and J.K. Burns. 2010. Degreening behavior in 'Fallglo' and 'Lee 9 Orlando' is correlated with differential expression of ethylene signaling and biosynthesis genes. Postharvest Biol. Technol. 58:185-193.

Kappel, F., R. Fisher-Fleming, and E.J. Hogue. 1995. Ideal pear sensory attributes and fruit characteristics. HortScience 30:988-993. Krautler, B. 2008. Chlorophyll breakdown and chlorophyll catabolites in leaves and fruit. Photochem. Photobiol. Sci. 7:1114-1120.

Kusaba, M., H. Ito, R. Morita, S. Iida, Y. Sato, M. Fujimoto, S. Kawasaki, R. Tanaka, H. Hirochika, M. Nishimura, and A. Tanaka. 2007. Rice nonyellow colouring1 is involved in light-harvesting complex II and grana degradation during leaf senescence. Plant Cell 19:1362-1375.

Lelièvre, J.M., A. Latche, B. Jones, M. Bouzayen, and J.C. Pech. 1997. Ethylene and fruit ripening. Physiol. Plant. 101:727-739. 
Livak, K.J. and T.D. Schmittgen. 2001. Analysis of relative gene expression data using real-time quantitative PCR and the $2^{-\Delta \Delta \mathrm{Ct}}$ method. Methods 25:402-408.

Narumi, T., R. Aida, A. Ohmiya, and S. Satoh. 2005. Transformation of chrysanthemum with mutated ethylene receptor genes: MDGERS1 transgenes conferring reduced ethylene sensitivity and characterization of the transformants. Postharvest Biol. Technol. 37:101-110.

Northwest Horticultural Council. 2013. Northwest Horticultural Council pear facts. 8 Aug. 2016. <http://www.nwhort.org/pearfacts.html>. Nukui, N., H. Ezura, and K. Minamisawa. 2004. Transgenic Lotus japonicas with an ethylene receptor gene Cm-ERS1/H70A enhances formation of infection threads and nodule primordia. Plant Cell Physiol. 45:427-435.

Oberhuber, M., J. Berghold, K. Breuker, S. Hortensteiner, and B. Krautler. 2003. Breakdown of chlorophyll: A nonenzymatic reaction accounts for the formation of the colorless nonfluorescent chlorophyll catabolites. Proc. Natl. Acad. Sci. USA 100:6910-6915.

Porat, P., B. Weiss, L. Cohen, A. Daus, R. Goren, and S. Droby. 1999. Effects of ethylene and 1-methylcyclopropene on the post-harvest qualities of 'Shamuti' oranges. Postharvest Biol. Technol. 15:155163.

Pruzuinska, A., G. Tanner, I. Anders, M. Roca, and S. Hortensteiner. 2003. Chlorophyll breakdown: Pheophorbide a oxygenase is a Riesketype iron-sulfur protein, encoded by the accelerated cell death 1 gene. Proc. Natl. Acad. Sci. USA 100:15259-15264.

Rüdiger, W. 2002. Biosynthesis of chlorophyll $\mathrm{b}$ and the chlorophyll cycle. Photosynth. Res. 74:187-193.

Sato, Y., R. Morita, M. Nishimura, H. Yamaguchi, and M. Kusaba. 2007. Mendel's green cotyledon gene encodes a positive regulator of the chlorophyll-degrading pathway. Proc. Natl. Acad. Sci. USA 104:14169-14174.

Schelbert, S., S. Aubry, B. Burla, B. Agne, F. Kessler, K. Krupinska, and S. Hörtensteiner. 2009. Pheophytinpheophorbide hydrolase (pheophytinase) is involved in chlorophyll breakdown during leaf senescence in Arabidopsis. Plant Cell 21:767-785.

Scheumann, V., S. Schoch, and W. Rüdiger. 1998. Chlorophyll a formation in the chlorophyll $\mathrm{b}$ reductase reaction requires reduced ferredoxin. J. Biol. Chem. 273:35102-35108.
Shemer, T.A., S. Harpaz-Saad, E. Belausov, N. Lovat, O. Krokhin, V. Spicer, K.G. Standing, E.E. Goldschmidt, and Y. Eyal. 2008. Citrus chlorophyllase dynamics at ethylene-induced fruit color-break: A study of chlorophyllase expression, posttranslational processing kinetics, and in situ intracellular localization. Plant Physiol. 148:108-118.

Sisler, E.C., T. Alwan, R. Goren, M. Serek, and A. Apelbaum. 2003. 1Substituted cyclopropenes: Effective blocking agents for ethylene action in plants. Plant Growth Regulat. 40:223-228.

Sisler, E.C. and M. Serek. 1997. Inhibitors of ethylene responses in plants at the receptor level: Recent developments. Physiol. Plant. 100:577-582.

Villalobos-Acuña, M., W.V. Biasi, E.J. Mitcham, and D. Holcroft. 2011. Fruit temperature and ethylene modulate 1-MCP response in 'Bartlett' pears. Postharvest Biol. Technol. 60:17-23.

Wang, Y. 2016. Storage temperature, controlled atmosphere, and 1methylcyclopropene effects on $\alpha$-farnesene, conjugated trienols, and peroxidation in relation with superficial scald, pithy brown core, and fruit quality of 'd'Anjou' pears during long-term storage. J. Amer. Soc. Hort. Sci. 141:177-185.

Watkins, C.B. 2006. The use of 1-methylcyclopropene (1-MCP) on fruits and vegetables. Biotechnol. Adv. 24:389-409.

Xie, X., T. Einhorn, and Y. Wang. 2015. Inhibition of ethylene biosynthesis and associated gene expression by aminothoxyvinylglycine and 1-methylcyclopropene and their consequences on eating quality and internal browning of 'Starkrimson' pears. J. Amer. Soc. Hort. Sci. 140:587-596.

Xie, X., J. Song, Y. Wang, and D. Sugar. 2014. Ethylene synthesis and ripening capacity of 1-MCP treated 'd'Anjou' pears affected by storage temperatures. Postharvest Biol. Technol. 97:1-10.

Yang, T.F., Z.H. Gonzalez-Carranza, M.J. Maunders, and J.A. Roberts. 2008. Ethylene and the regulation of senescence processes in transgenic Nicotiana sylvestris plants. Ann. Bot. (Lond.) 101:301310.

Yang, X.T., J. Song, L. Campbell-Palmer, S. Fillmore, and Z. Zhang. 2013. Effect of ethylene and 1-MCP on expression of genes involved in ethylene biosynthesis and perception during ripening of apple fruit. Postharvest Biol. Technol. 78:55-66. 